\title{
An important new health policy voice
}

\author{
Richard B. Saltman * ${ }^{*}$
}

\begin{abstract}
In the 10 years since its founding, the Israel Journal of Health Policy Research has established itself as an important voice in Israeli and international health policy. The Journal's ability to combine national and international perspectives on key issues in health services delivery and health systems analysis has developed a valuable new arena for academic research about the increasingly complex post-COVID future of health care systems.
\end{abstract}

Keywords: Health systems policy, Health systems analysis, Health system research, Israeli Health System, Comparative Health Systems

Journals sit at the very heart of the entire academic enterprise. They are essential not just for individual academics to demonstrate their intellectual acumen, but also, and more importantly, to document and transmit core intellectual knowledge among contemporary and future researchers and practitioners. Successful journals help define our understanding of what is true, and help shape academe's continually emerging assessment of what further knowledge we require to understand the policy phenomena we confront.

This essential function is particularly important in the complex multi-disciplinary arena that is health policy. Composed of widely varying academic disciplines (economics, political science, sociology, organization theory, management theory along with myriad sub-disciplines), with different, and often divergent, structural environments in different national sometimes within-country regional health delivery arrangements, subject to the complexities of varying national political systems and political cultures, health policy is even more dependent on strong, well-edited, and well-managed journals. Every academic knows the rare pleasure of discovering a smart new journal that publishes important new thinking in the field and that, perhaps, they can publish in themselves.

*Correspondence: rsaltma@emory.edu

Rollins School of Public Health, Emory University, Atlanta, GA, USA
The arrival of the Israel Journal of Health Policy Research was such an event. The Journal has grown in breadth, depth, and, consequently, stature throughout its 10 year history, resulting in what is now an important international as well as national voice in the increasingly complex COVID-driven policy environment that developed country health systems now confront. Faced with the necessity of re-assessing and re-evaluating their core regulatory and operational arrangements, countries from Sweden [1] to the United Kingdom [2, 3] and Spain [4], as well as the European Union in conjunction with the WHO Regional Office for Europe through its high level commission on health system resilience [5, 6], are seeking better answers and better strategies for dealing with future public health crises. It is in part to the credit of the Israel Journal of Health Policy Research that Israeli policymaking before and during the COVID-19 epidemic, especially around population vaccination strategies, rates, and outcomes, has played an important international role in this ongoing international debate [7].

Academic journals are not easy enterprises to develop, however. They are notoriously difficult to start, to staff, and to steer in an effective and successful manner. That developmental process takes enormous organizational, intellectual, and sometimes physical fortitude, much of it long before the outcome can be known. The Israel Journal wisely positioned itself strategically astride both the rapidly developing Israeli health policy world, and original author(s) and the source, provide a link to the Creative Commons licence, and indicate if changes were made. The images or other third party material in this article are included in the article's Creative Commons licence, unless indicated otherwise in a credit line to the material. If material is not included in the article's Creative Commons licence and your intended use is not permitted by statutory regulation or exceeds the permitted use, you will need to obtain permission directly from the copyright holder. To view a copy of this licence, visit http://creativecommons.org/licenses/by/4.0/. The Creative Commons Public Domain Dedication waiver (http://creativecommons.org/publicdomain/zero/1.0/) applies to the data made available in this article, unless otherwise stated in a credit line to the data. 
the broader policy debates across Europe and North America.

Initial international discussions about the proposed journal's focus were held at a meeting of the International Advisory Committee of the Israel National Health Policy Institute, held during its widely attended Global Conference on Health Policy. Suggestions from senior academics from organizations like the European Observatory on Health Systems and Policies, the World Bank, University College London, London School of Hygiene and Tropical Medicine, and other major research institutions in Europe and the United States helped shape the international component of the new journal. Many of these individuals later contributed commentaries or articles as the Journal took form, strengthening its scope and reach, and confirming the wisdom of the founding editors' combined domestic and international vision.

It is to the great credit of the Journal's editors and sponsors that it has come so far so fast. Those of us in the international community who have worked with them look forward to continuing this wonderful interaction in the coming years.

\section{Acknowledgements}

Not applicable.

\section{Authors' contributions}

RBS alone wrote this manuscript. The author read and approved the final manuscript.

\section{Funding}

No funding was granted or used for this manuscript.
Consent for publication

Not applicable.

\section{Competing interests}

I have no competing interests.

Received: 11 November 2021 Accepted: 12 November 2021

Published online: 15 December 2021

\section{References}

1. Ahlander J, Pollard N. Sweden acted too slowly as pandemic swept country, Commission Finds | World News | US News. https://www.usnews. com/ (2021).

2. UK Parliament. Coronavirus: lessons learnt-Committees_UK Parliament (2021).

3. Vaughan A. Covid-19: UK's slow response was a 'serious' error, say MPs | New Scientist. https://www.newscientist.com/article/2293227-uks-slowresponse-to-covid-19-was-a-serious-error-say-mps/\#ixzz7BGZuWw5I (2021).

4. Gonzalez M, Lopez-Fonseca O. Covid-19 in Spain: Spanish government blames lack of trustworthy data on slow response to pandemic | Society | El País English Edition. https://elpais.com (2021).

5. WHO Europe. Drawing light from the pandemic: a new strategy for health and sustainable development. For the Pan-European Commission on Health and Sustainable Development. 9789289051798-eng.pdf. https:// www.who.int/ (2021).

6. European Observatory on Health Systems and Policies. Drawing light from the pandemic: a review of the evidence. Edited by Professor Martin McKee. McKee Obs Pandemic Evidence 2021.pdf (2021).

7. Rosen B, Waitzberg R, Israeli A, Hartel M, Davidovitch N. Addressing vaccine hesitancy and access barriers to achieve persistent progress in Israel's COVID-19 vaccination program. Israel J Health Policy Res. 2021:10:43. https://doi.org/10.1186/s13584-021-00481-x

\section{Publisher's Note}

Springer Nature remains neutral with regard to jurisdictional claims in published maps and institutional affiliations.

\section{Availability of data and materials \\ Not applicable.}

Ethics approval and consent to participate

Not applicable. 